\title{
Impact of Exchange Rate Change on Import Price
}

\author{
Sri Isnowati, Mulyo Budi Setiawan \\ Faculty of Economics and Business \\ Universitas Stikubank (Unisbank) \\ Semarang, Indonesia \\ isnowati@gmail.com
}

\begin{abstract}
The aim of this research was to examine the interdependence between import price, exchange rate and national income. The data analysis method used was structural vector autoregressive (svar). The data used in this research was quarterly data from 1997.3 through 2013.4. The analysis was conducted on the impulse response function (IFRS) and forecast error variance decompositions (FEDVs) to determine the effect of exchange rate to import price and national income. The results show that exchange rate shock has positive effect on import price and has negative effect on national income. Furthermore, FEDVs analysis show that the variations of import price were largely determined by the import price, and the exchange rate variations were largely determined by the exchange rate itself. Meanwhile, the variations in national income were largely determined by the exchange rate variable.
\end{abstract}

Keywords: import price, exchange rate, national income, SVAR.

JEL:

\section{INTRODUCTION}

One of the important issues in international economy is the relationship between exchange rate movements and changes in the price of traded goods. The effect of exchange rate change on domestic price change is known as Exchange Rate PassThrough (ERPT). When there is depreciation to the exchange rate of a domestic currency against foreign currencies, it will cause a rise in inflation as a result of the process of pass through effect. (1) state that exchange rate change is transmitted to domestic price through three channels; imported goods consumed, imported intermediate goods, and domestic goods in foreign currency prices.

From many studies on Exchange Rate Pass Through, there was no uniformity regarding the definition of "pass through". Some researchers focused on the relationship between the changes in exchange rate to import price $(2,3)$, and some other researchers linked the changes in exchange rate with consumer price index (4-6). From the researches, the Exchange Rate Pass Through working through Consumer Price Index is usually less sensitive to the changes in exchange rate due to the Consumer Price Index in it including non-tradable goods (7).

There are the debates on the factors that influence Exchange Rate Pass Through. Some reviewed the aspects of macro and micro. The study of macro aspect stated that the factors affecting ERPT include inflation and exchange rate volatility, but that of micro aspects indicated that ERPT is influenced by the factors such as the level of product differentiation and market power. (8) is the reference to the study of ERPT on macro aspects,(3) examined the micro phenomenon, and (9) examined pass-through as the phenomenon of macro or micro. The studies on pass through indicated that macro variables are the variables which are directly related to the monetary policy implemented by the monetary authority, such as inflation. The results of the study on macro variables show that ERPT degradation occurred after the 1990s was not permanent.

Meanwhile, the micro study results show the ambiguous role of product differentiation as two different effects; first, the more differentiated the product, the higher the market power, so that the higher pass-through is consistent with the research results of (10)Bacchetta. Second, the more differentiated the product, the higher the influence of mark-up on pricing-tomarket, so it causes the lower degree of ERPT (3).

As a country that adheres to an open economy, Indonesia's economy is strongly affected by exchange rate movements. The exchange rate movement of Rupiah cannot be separated from the dynamics in the external and domestic macro economy. The financial crisis in 1997 made the government of Indonesia reconstruct the implementation of monetary policy by applying free floating in Indonesian exchange rate. Not long afterwards, Indonesia adopted the inflation targeting regime in 2000 .

The drastic changes in monetary policy caused the changing policy implications in Indonesia. After embracing free floating, the exchange rate volatility increased higher than before embracing free floating. At the same time, foreign currency reserves decreased and the interest rates rose. The inflation in Indonesia dropped very quickly after the application of the new monetary policy, and Indonesia was also increasingly open to international trade.

The higher the volatility of the exchange rate, it will have the effect on the changes in domestic prices in Indonesia. Based on the research of (11), exchange rate pass-through in developing countries is higher than that in developed countries. In line with this, this study examined how the Exchange Rate Pass Through in Indonesia and how the shock of the exchange rate to import prices in Indonesia.

\section{LITERATURE REVIEW}

After the 1990s, the Exchange Rate Pass Through was one of the important issues in the study of international economics. Exchange Rate Pass-Through (ERPT) is defined as the impact 
of exchange rate changes on domestic prices. To test ERPT, it can be denoted as follows:

$$
u_{t}=\beta_{0}+\beta_{1} \varepsilon_{t}+\beta_{2} x_{t}+\varepsilon_{t}
$$

Where: $\|_{t}$ is domestic price, $\ell_{t}$ is exchange rate, and $x_{t}$ is other control variable.

The research on ERPT focuses on price adjustment on exchange rate changes $\left(\ell_{t}\right)$ for the transactions among importing countries. Based on the equation (1), the coefficient of $\beta_{1}$ indicates the coefficient of pass through.

ERPT is generally divided into two phases: in the first phase, it analyzes the changes in exchange rate to import prices and, in the second stage, it analyzes the changes in import price to consumer prices. However, in general, many studied the direct exchange rate of pass-through to consumer prices.

\section{Previous Research}

1) (12) examined the effect of exchange rate changes on consumer prices in Ghana by using the methods of SVAR. The research results showed that the pass through of exchange rate to consumer prices is incomplete and high. It indicated that the depreciation of exchange rate is an important source of inflation in Ghana. By using thevarianse decomposition analysis, it showed that monetary expansion is more important than exchange rate in explaining inflation. One implication of the policy wasthat the decreasing of inflation in Ghana should be focused on monetary policy and exchange rate stability.

2) (13) examined the exchange rate pass-through to domestic prices using the method of SVAR and single equation aproach in four countries in Asiaafter the crisis of 1997. The results showed that the degree of exchange rate pass-through is incomplete. The highest degree of exchange rate pass through is in import prices, the second highest is producer price index, and the lowest is consumer price index. The impact of import price shock is greater than the exchange rate shock in the domestic price movements in the four countries studied. Economic disclosure has weak effect on the degree of exchange rate pass through.

3) (14) examined the exchange rate pass-through to consumer prices in Nigeria using the method of SVAR. The results showed that the exchange rate pass-through has the great effect on inflation in Negeria. In Nigeria,it was found that exchange rate plays bigger role than the amount of money circulating in the rise in inflation.

4) (15) examined the exchange rate pass through in 12 countries of emerging market in Asia, Latin America, Central Europe and Eastern Europe using the method of VAR. The results showed that ERPT degree is greater in developing countries than that in developed countries by using import and consumer prices. It was also found that there was a positive association between the degree of ERPT and inflation. Besides, the results also showed positive association between import openness and ERPT.

\section{METHOD}

\section{A. Data}

The data used in this research was the secondary data published by the Central Bureau of Statistics, the Bank of Indonesia and the International Financial Statistics (IFS). The data used was quarterly time series from the year of 1997.3 to 2013.4. The import price $(\mathrm{P})$ data is the data of import price index in Indonesia. The exchange rate data is the exchange rate against the US dollar. The national income data is the data of real Gross Domestic Product (GDP) to the base year of 2005. In analyzing the data, the data were then transformed in the form of $\log$.

\section{B. Research Model}

The model used in this research was as follows:

$$
P_{t}=\beta_{0}+\beta_{1} e_{t}+\beta_{2} y
$$

Where: $\mathrm{P}$ is import price, $\mathrm{e}$ is exchange rate, and $\mathrm{y}$ is national income.

\section{Data Analysis Method}

In this study, the data analysis was conducted in a simultaneous way which was intended to determine the association among the variables used in the study. The method used to determine the interdependence was the method of Structural Vector Autoregressive (SVAR).

The main objective of SVAR estimate is to obtain non recursive orthogonalization error term for the analysis of impulse responses, whereas the alternative recursive orthogonalization of Choleskyrequires to include sufficient restriction for identifying orthogonal error term. An endogenous variable vector with $\mathrm{k}$ elements is denoted by $\mathrm{y}$, and the residual covariance matrixes $\Sigma=E\left[\varepsilon_{l}, \varepsilon_{t}\right]$, then the model of SVAR can be written as follows:

$$
A e_{t}=B u_{t} \ldots \ldots(3)
$$

Where $\varepsilon_{t}$ and $u_{t}$ is a vector with the length of $\mathrm{k}, u_{l}$ is the residue that can observed (reduced form), $u_{l}$ is the unobserved structural innovation. $\mathrm{A}$ and $\mathrm{B}$ are the estimated matrices of $\mathrm{k} * \mathrm{k}$. Structural innovation was assumed to be orthogonal, the matrix covariance is identity matrix, $E\left[u_{l}, u_{t}\right]=\mathrm{I}$. the assumption of orthogonal innovations included the restriction identification of $\mathrm{A}$ and $\mathrm{B}$ as $A \Sigma A^{\prime}=B{ }^{\prime}$

In the analysis of the VAR, the steps taken are:

\section{1) Data Generating Process (DGP)}

Before going into the analysis stage of VAR model, Data Generating Process (DGP) has to be previously conducted. This is important because in the model of multivariate timeseries the data mostly used contains the unit root that will make the estimation becomes false (spurious regression) (Gujarati, 2004). The stages in Data Generating Process prior to the analysis by modeling include data stationary test, cointegration test and lag length test.

\section{a) Data Stationarity Test}


Stationarity test is conducted using Augmented DickeyFuller (ADF). The test using ADF is divided into three, i.e.: $\mathrm{ADF}$ by involving constants $(\mathrm{C}, \mathrm{n}), \mathrm{ADF}$ which involves constant and time trend $(\mathrm{T}, \mathrm{n})$, and $\mathrm{ADF}$ which does not involve constant and time trend $(\mathrm{N}, \mathrm{n})$.

\section{b) Determination of Lag Length}

The determination of lag length is an important thing to do in the model of VAR Structural because SVAR model (continued development of VAR model) is very sensitive to lag length (Enders, 2015).

The determination of optimal lag can be used to set the value of lag based on the test of Akaike Information Criteria (AIC) and Schwarz Information Criterion (SIC) which result in minimum value. In order to determine optimal lag, it can also be conducted by comparing the highest value of Adjusted $\mathrm{R}^{2}$ among the existing candidates (16).

\section{RESULTS AND DISCUSSION}

\section{A. Data Stationarity}

The important issue in the analysis of time series data is the problem of data stationarity. The procedure to test the data stationarity in this research used the Augmented Dickey Fuller test (ADF)

Table 1 Unit Root test

\begin{tabular}{|l|l|l|l|}
\hline \multicolumn{1}{|c|}{ Variable } & \multicolumn{1}{|c|}{ Degree } & ADF & Conclusion \\
\hline P & Level & $-2,1468$ & I $(1)$ \\
\hline & First Defferece & $-10,0601$ & \\
\hline E & Level & $-4,7410$ & I(1) \\
\hline & First Defferece & $-6,3470$ & \\
\hline GDP & Level & $-4,5555$ & I(1) \\
\hline & First Defferece & $-5,9783$ & \\
\hline
\end{tabular}

Table 1 shows the result of unit root test. The tests of unit root show that the ADF critical value by the level of confidence of 5 percent is -2.9036 . Thus, the count statistics that indicates the number exceeding critical value are exchange rate and output, while the import price variable is lower than the critical value. Therefore, the null hypothesis stating that unit root is present cannot be rejected or the variable of import price is not stationary.

From these results, the unit root test was continued at first deference to check if the variable integrates in the same degree. The testing of unit root in the level of first deference showed the critical value of the ADF with the level of confidence of 5 percent is -2.9041. the value of count statistic of the variable of import prices, exchange rates and GDP based on the ADF test has greater value than the critical value of ADF. Based on the ADF test, the test of null hypothesis stating the existence of unit root is rejected. The results show that the variables of import prices, exchange rates, and GDP are stationary at the level of first deference so that the data are cointegrated in grade $1, \mathrm{I}(1)$.

\section{B. Cointegration}

Further testing was the cointegration test using Johansen test of Cointegration to test the long-term relationship in the analysis using structural vector auto regresion (SVAR). The interplay can be seen from the cointegration occurred in the variables. When there is a cointegration among variables, the interplay runs thoroughly and the information is spread in parallel.

The steps of cointegration test in this research were started by testing the null hypothesis stating the absence of long-term relationships among the variables. The testing was conducted by comparing the value of trace statistic with the critical value at $\alpha$ of 5 percent

TABLE 2 COINTEGRATION TEST

Series: LP LS LY

Lags interval (in first differences): 1 to 2

Unrestricted Cointegration Rank Test (Trace)

\begin{tabular}{llccc}
\hline \hline $\begin{array}{c}\text { Hypothesized } \\
\text { No. of CE(s) }\end{array}$ & Eigenvalue & $\begin{array}{c}\text { Trace } \\
\text { Statistic }\end{array}$ & $\begin{array}{c}\mathbf{0 . 0 5} \\
\text { Critical Value }\end{array}$ & Prob.** \\
\hline \hline & & & & \\
None $*$ & 0.387318 & 40.25382 & 24.27596 & 0.0002 \\
At most 1 & 0.098090 & 8.899637 & 12.32090 & 0.1750 \\
At most 2 & 0.035182 & 2.292226 & 4.129906 & 0.1535 \\
\hline \hline
\end{tabular}

Trace test indicates 1 cointegratingeqn(s) at the 0.05 level

* denotes rejection of the hypothesis at the 0.05 level

***MacKinnon-Haug-Michelis (1999) p-values

Table 2 shows the result of cointegration test. Based on the method of Johansen test of cointegration, it appears that the trace statistic is greater than the critical value, so it can be concluded that the variables of LP, LS and LY in the long term are mutually cointegrated.

\section{Determination of Lag Length}

The estimation of SVAR model was begun by determining the optimal lag length. The determination of the optimal lag length is important for modeling SVAR. When the determined optimal lag is too short, it does not seem to be able to explain the dynamism of the model as a whole. On the other hand, when the optimal lag is too long, it will result in an inefficient estimation due to the reduced degree of freedom (especially in the models with small samples).

The determination of the optimal lag length can use several criteria, such as the methods of Akaike Information Criteria (AIC) and Schwarz Information Criteria (SIC), Hanan-Quin Criteria (HQ), Likelohood Ratio (LR) and Final Prediction Error (FPE). 
Table 3 Lag Length
1) Figure 1 Response of Import Prices to Exchange Rates Figure 1 shows that the observation of the effects of

\begin{tabular}{llllllll}
\hline \hline Lag & LogL & \multicolumn{1}{c}{ LR } & FPE & AIC & SC & HQ \\
\hline \hline 0 & 122.5465 & NA & $4.51 \mathrm{e}-06$ & -3.795128 & -3.693074 & -3.754990 \\
1 & 260.5780 & 258.5352 & $7.51 \mathrm{e}-08$ & -7.891366 & $-7.483150^{*}$ & -7.730813 \\
2 & 274.5841 & 24.89972 & $6.42 \mathrm{e}-08$ & -8.050290 & -7.335911 & -7.769321 \\
3 & 282.6874 & 13.63414 & $6.64 \mathrm{e}-08$ & -8.021823 & -7.001283 & -7.620440 \\
4 & 302.2081 & $30.98524^{*}$ & $4.80 \mathrm{e}-08^{*}$ & $-8.355814^{*}$ & -7.029111 & $-7.834015^{*}$ \\
\hline \hline
\end{tabular}

e. * indicates lag order selected by the criterion

Table 3 shows the result of lag length criteria. Based on the testing of optimal lag length in Table III, it appears that, based on the criteria of AIC and HQ, the optimal lag length is 4 .

\section{Impulse Response}

The analysis of impulse response functions is the core of the analysis of SVAR model. The estimation to impulse response function was conducted to examine the impact of shocks on the variable of innovation and the other variables. the estimation using the assumptions of each innovation variable is not correlated with one another so that the searches for the effect of a shock may be direct.

The impulse response function shows how the variables used in future study respond to the shock/ exchange rate shock. The IRFs analysis in this section tracked the impact of exchange rate shocks (LS) on the variables of import price (LP) and national income (LGDP). The IFRS analysis was conducted to innovation by increasing the value of exchange rate variable of one standard deviation at the beginning of the period resulting in quarterly changes over a period of ten quarters or two and a half years. The selection of ten quarter was expected to be relatively precise to observe the changes in the variables of price (LP) and national income (LGDP) to the shock innovation of exchange rate.

The figure of impulse response shows the response of a variable due to the shock of the other variables for some periods after the shock. When the images of impulse response show the movement which is getting closer to balance (convergence) or returns to the previous equilibrium, it means that the response of a variable due to the shock does not leave permanent effect on the variables.

Response of LP to LS

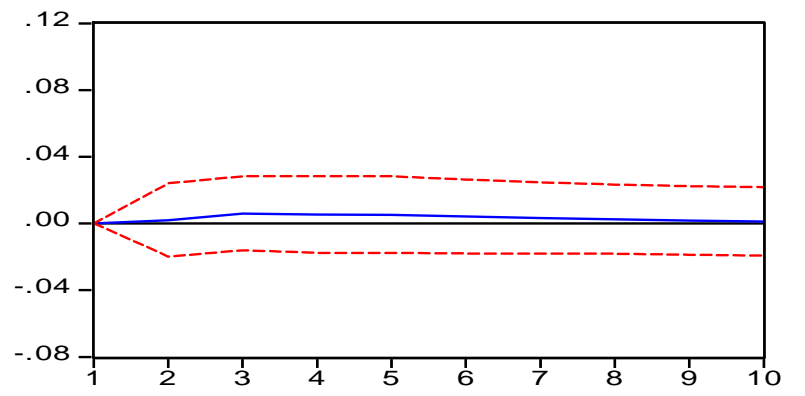

Fig. 1. Source: Processed Data responses received by import prices due to the shock of exchange rate over ten quarters is constant, but do not indicate the nature of convergence

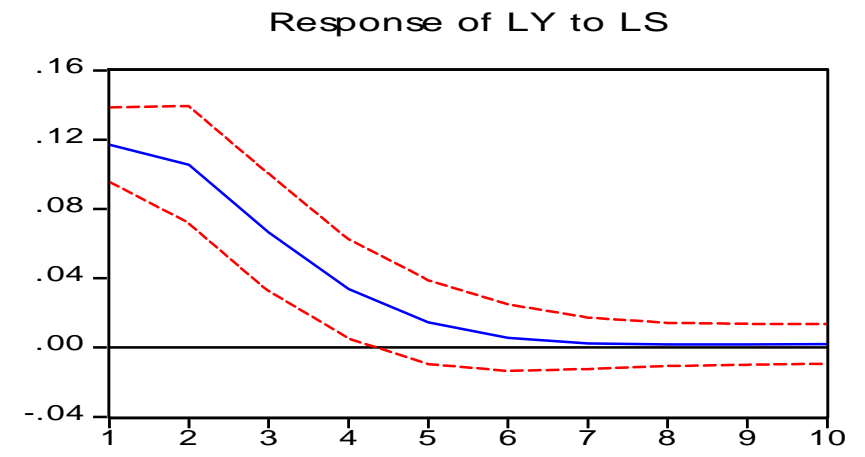

Fig. 2. Source: Processed Data

\section{2) Figure 2 GDP response to Exchange Rate}

Figure 2 also shows the output response observations to exchange rate. At the beginning of the period, the output response to exchange rate was positive. After passing through the second quarter, it decreased and then experienced a stable response after the seventh quarter. However, the output response to exchange rate had a tendency not to be convergent until the tenth quarter.

Based on the observations from the figure of impulse response, the variables of import prices and output show that the equilibrium is not convergent, and it indicates that the adjustment process takes a long time.

\section{E. Variance Decomposition}

Variance decomposition is to separate the effect of each innovation variable individually to the response received by a variable including innovation to the variable itself. This analysis is useful for estimating the contribution of the variance percentage of a variable in SVAR system due to the shocks.

Table 4 Variance Decomposition

\begin{tabular}{llccc}
$\begin{array}{c}\text { Variance } \\
\text { Decomposition } \\
\text { of LP: } \\
\text { Period }\end{array}$ & S.E. & $\boldsymbol{L P}$ & $\boldsymbol{L S}$ & $\boldsymbol{L Y}$ \\
\hline \hline & & & & \\
1 & 0.095877 & 100.0000 & 0.000000 & 0.000000 \\
2 & 0.121177 & 98.81191 & 0.027311 & 1.160783 \\
3 & 0.141673 & 98.89082 & 0.199593 & 0.909589 \\
4 & 0.158092 & 98.84797 & 0.275441 & 0.876587 \\
5 & 0.171822 & 98.90256 & 0.324855 & 0.772581 \\
6 & 0.183639 & 98.97237 & 0.335099 & 0.692532 \\
7 & 0.193976 & 99.04832 & 0.329067 & 0.622617 \\
8 & 0.203161 & 99.11798 & 0.314392 & 0.567629 \\
9 & 0.211417 & 99.17587 & 0.297103 & 0.527024 \\
10 & 0.218911 & 99.22065 & 0.279779 & 0.499576
\end{tabular}


(Table 4, cont.)

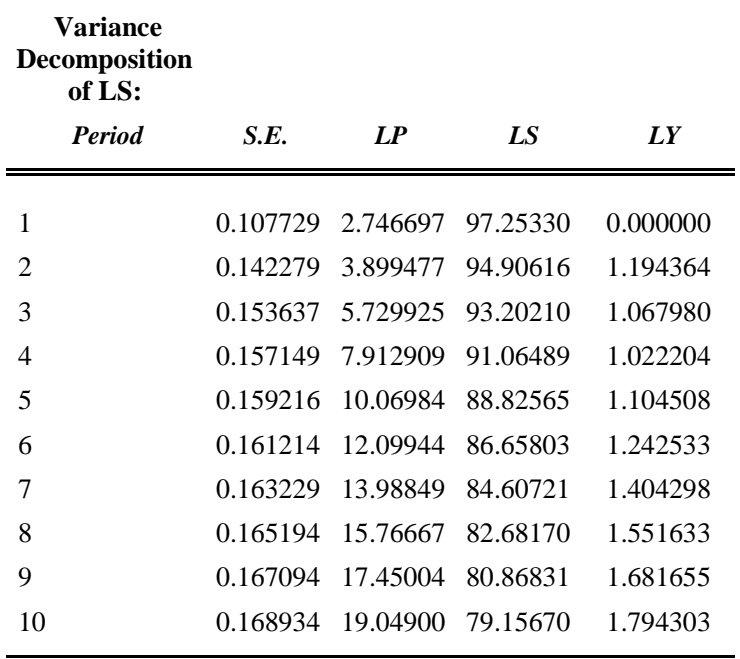

\begin{tabular}{|c|c|c|c|c|}
\hline $\begin{array}{c}\text { Variance } \\
\text { Decomposition } \\
\text { of LY: } \\
\text { Period }\end{array}$ & & & & $I Y$ \\
\hline Period & S.E. & $L P$ & $L S$ & $L Y$ \\
\hline 1 & 0.120730 & 1.362596 & 94.09835 & 4.539058 \\
\hline 2 & 0.164213 & 1.737530 & 92.13760 & 6.124875 \\
\hline 3 & 0.179343 & 2.387762 & 91.02267 & 6.589573 \\
\hline 4 & 0.183822 & 3.092791 & 89.99515 & 6.912056 \\
\hline 5 & 0.185267 & 3.737054 & 89.21028 & 7.052664 \\
\hline 6 & 0.186004 & 4.286659 & 88.59469 & 7.118651 \\
\hline 7 & 0.186539 & 4.747398 & 88.10349 & 7.149111 \\
\hline 8 & 0.186981 & 5.136610 & 87.69679 & 7.166598 \\
\hline 9 & 0.187358 & 5.468859 & 87.35374 & 7.177401 \\
\hline 10 & 0.187685 & 5.755365 & 87.06080 & 7.183835 \\
\hline $\begin{array}{c}\text { Cholesky } \\
\text { Ordering: LP } \\
\text { LS LY }\end{array}$ & & & & \\
\hline
\end{tabular}

Table 4 describes the variance decomposition. Based on the analysis, it indicates that, in the first period, the contribution of exchange rate shocks to import prices was not noticeable at all. However, after the third quarter, it showed a significant contribution by 19 percent. In the third quarter, the contribution of exchange rate shock continued to increase until the sixth quarter reaching 33 percent. After the sixth quarter, it declined gradually. Furthermore, the contribution of output to price ratio is very small, only less than one percent.

For the decomposition variance of exchange rate, the exchange rate response in the first period was almost entirely (97.25 per cent) due to exchange rate shocks, and the rest was explained by the variable of price ratio. From the second to tenth quarter, this pattern did not change because the response rate was 79.16 percent due to the exchange rate shocks and 19.04 per cent due to the import prices.
The other findings are the variance decomposition for national income. The ability of exchange rate signifantly influenced national income at the beginning of the period (94.09 percent) compared to price ratio (1.36 percent) or output level (4.53 percent). The same pattern did not change until the tenth quarter. The ability of exchange rate significantly affected national income by 87.06 percent.

\section{CONCLUSION}

From the analysis, it can be concluded:

Based on the analysis of impulse response (IRFs), it indicates that the exchange rate shocks to the import prices examined show positive effect. Meanwhile, the effect of the exchange rate shock on the national income is positive and higher than the exchange rate shocks to the import prices. The exchange rate shock to the national income was higher in the first quarter, and then it fell from the second quarter to the next. Both the responses of import prices and national income equally showed the response away from the balance point (divergence). This means that the response accumulation of the variables of real prices and national income was gradually getting stronger and gave permanent effects (persistent).

Furthermore, the analysis of forecast error variance decompositions (FEVDs) found that the exchange rate had a more powerful effect on the national income compared with the import prices. This fact shows that the variability of the exchange rate was smaller than the variability value of the national income.

\section{REFERENCES}

[1] Lian An. Exchange Rate Pass-Through: Evidence Based on Vector Autoregression with Sign Restrictions. MPRA Paper. 2006;No. 527.

[2] Parsley DC. Exchange rate pass-through in a small open economy: Panel evidence from Hong Kong. International Journal of Finance \& Economics. 2003;8:99.

[3] Campa JM, Goldberg LS, González-Mínguez JM. Exchange-Rate PassThrough to Import Prices in the Euro Area. NBER Working Paper No 11632. 2005.

[4] Bouakez H, Rebei N. Has Exchange Rate Pass Through Realy Declined? Evidence of Canada. Journal of International Economics. 2008;75:24967.

[5] Takhtamanova YF. Understanding Change in Exchange Rate Pass through. Journal of Macroeconomics. 2010;32:1118-30.

[6] Beirne J, Bijsterbosch M. Exchange rate pass-through in central and eastern European EU Member States. Journal of Policy Modeling. 2011;33:241-54.

[7] Ghosh A, Rajan RS. Macroeconomic Determinants of Exchange Rate Pass-Through in India Working Paper Colorado College. 2007.

[8] Taylor J. Low Inflation, Pass Through and pricing Power of Firm. European Economic Review 2000;44(7):1389-408.

[9] Campa JM, Goldberg LS. Exchange Rate Pass Through into Import Prices : a Macro or Micro Phenomenon? NBER Working Paper. $2002 ; 8934$.

[10] Bacchetta P, Wincoop Ev. Why do Consumer Price React Less Than Impor Price to Exchange Rat. Journal of the European Economic Association. 2003;1(2-3:662 - 70.

[11] M Devereux andEngel C. Endogeneous Currency of Price Setting in Dynamic Open Economy Modle. Working Paper. 2001;8559. 
[12] Sanusi A. Exchange Rate Pass Through to Consumer Prices in Ghana: Evidence From Vector Autoregression. Munich Personal RePEc Archive (MPRA) Paper. 2010;29491.

[13] Sek SK, Kapsayamova Z. Exchange Rate Pass Through and Volatility: Impact On Domestic Prices In Four Asian Countries. Munich Personal RePEc Archive (MPRA) Paper. 2008;11130.
[14] A AO, E S. Exchange Rate Pass Through to Consumer Prices in Negeria. European Scentific Journal. 2013;9(25).

[15] Zorzi MC, Hahn E, Sánchez M. Exchange Pass Through In Emerging Market. Working Paper European Central Bank. 2007; No 739.

[16] Enders W. Applied Econometric Time Series. United States of America Wiley;2015. 